\title{
Mininge
}

\section{Diagnosis about iron ore mine haul roads in the Quadrilátero Ferrífero - Itabira Complex case}

http://dx.doi.org/10.1590/0370-44672014670169

\author{
Maíra dos Santos Reis \\ MSc em Engenharia Mineral \\ PPGEM/UFOP \\ Ouro Preto/MG - Brasil \\ mairasreis@gmail.com
}

\section{Waldyr Lopes de Oliveira Filho \\ Prof. PhD, DEMIN/UFOP \\ Ouro Preto/MG - Brasil \\ waldyr@em.ufop.br}

\section{Ely Oliveira \\ Eng. Civil, Vale \\ Itabira/MG - Brasil \\ ely.oliveira@vale.com}

\section{Gladsney Pena}

Eng. de Minas, Vale

Itabira/MG - Brasil

gladsney.pena@vale.com

\section{Diagnóstico do estado de projeto, construção e manutenção de estradas de mina de minério de ferro no Quadrilátero Ferrífero - caso complexo de Itabira}

\begin{abstract}
Although mine haul roads only provide support for mining activities, their role can be quite significant in any effort to optimize transportation with trucks in open pit mining. In 2009, an inventory about the design, construction and maintenance conditions of these structures in mines in the Quadrilátero Ferrífero was undertaken through a partnership between a large mining company and UFOP. Although the conditions of the roads could be considered broadly satisfactory, several points with potential for improvement were observed. This partnership was recently resumed on enlarged bases for an upgrade, but with a quantitative approach and in a representative mine. The report of this mine haul road diagnosis with a feedback on how we can do more and better for mine haul roads are presented in this work.
\end{abstract}

Keywords: surface mine haul road; haul road design; haul road construction; mine maintenance.

\section{Resumo}

Embora as estradas de mina sejam apenas apoio para as atividades de mineração, seu papel pode ser bastante significativo em qualquer esforço de otimização do transporte na lavra a céu aberto realizado com caminhões. Em 2009, um inventário sobre as condições de projeto, construção e manutenção dessas estruturas em minas no Quadrilátero Ferrífero foi realizado através de uma parceria entre uma grande empresa de mineração e a UFOP. Embora as condições das vias pudessem ser consideradas, em geral, satisfatórias, vários pontos com potencial de melhoria foram observados. Essa parceria foi retomada recentemente com bases ampliadas, para uma atualização, porém com uma abordagem quantitativa e em uma mina representativa daquele universo. O relato desse diagnóstico com comentários de como se pode fazer mais e melhor para as estradas de mina é apresentado nesse trabalho.

Palavras-chave: estradas de mina a céu aberto; projeto de estradas; construção de estradas; manutenção de mina.

\section{Introduction}

Mine haul roads make possible the transportation of ore and waste in a majority of the open pit mines, be- ing considered a unitary operation. Its importance is recognized, but there is a certain difficulty in associating good roads with profit and emphasizing that they deserve more attention in the overall mining management. Because of 
this, together with the lack of haul road condition diagnostics and a proactive attitude for change, our haul roads are in a substandard stage when it comes to quality and efficiency.

In this scenario, an inventory of the mine haul roads regarding their general conditions and current practice in design, construction and maintenance for mines in the Quadrilátero Ferrífero (QF) was undertaken in 2009 within an agreement between The Federal University of Ouro

\section{Materials and methods}

The diagnosis of mine haul roads was divided in three phases: 1) selection of a site; 2) evaluation of current practice; 3 ) consolidation of the results. In the first phase, representative mine sites of the QF were sought based on information collected by Oliveira Filho et al. (2010). Three facilities were initially pointed out. However, after careful analyses, it was decided to focus studies in the Itabira Complex, owned by VALE. The second phase demanded much more time and research efforts. For a deep understanding of the practice, detailed field work, comprehen-

\section{Results and discussion}

\section{Selected mine facility}

The preliminary chosen mine sites were Itabira Mine Complex, Fábrica Nova Mine and Brucutu Mine. However, as it was learned that Brucutu Mine was considered as the benchmark mine of QF, very few problems related to haul roads were expected in that place. Regarding the Fábrica Nova Mine, it was considered to present conditions

\section{General conditions}

Conceição Mine is an open pit site. Because of that, both haul road foundations (sub-grade) and construction material have high bearing capacity and shear strength. In Minas do Meio Mines, ore

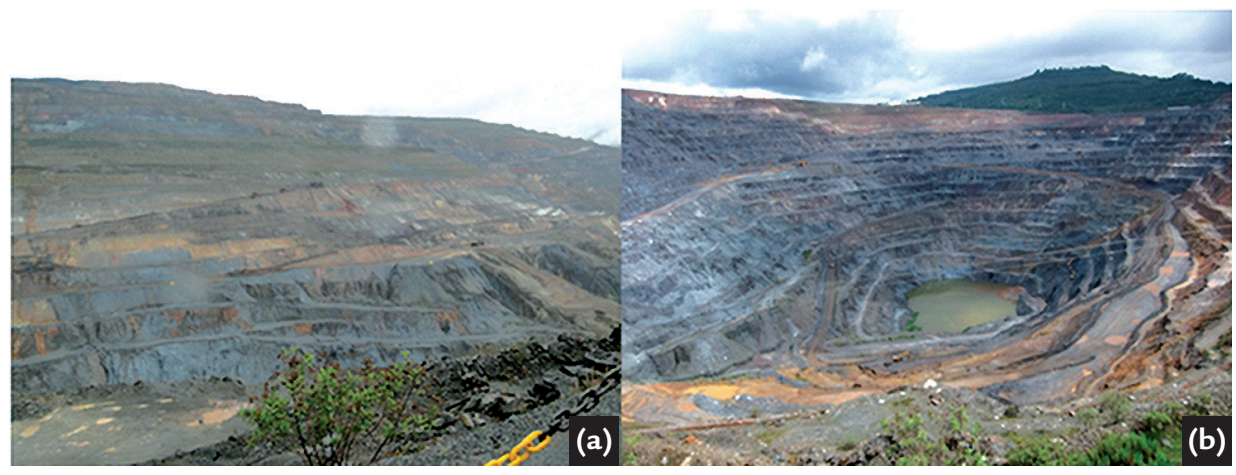

Preto (UFOP) and a big mining company (Oliveira Filho et al., 2010). In that work, it was verified that road implementation and management occurred in an empirical form, with simple methods and limited scope. The depth level of design and construction control of those structures was broadly not compatible with the needs, requiring large efforts in maintenance (human and financial resources). Furthermore, a lack of standard procedures was noticed: each facil- sive search and review of documents were necessary. Moreover, a strong interaction with professionals directly engaged with the mine haul roads in all aspects and levels was required. To fulfil this last task, it was found necessary to promote the leveling of concepts and nomenclature standardization in order to facilitate communication amongst the research participants and allow a reliable current practice evaluation. The elements that allowed performing this phase consisted basically of preparation and application of a leveling course (theory and practice). very similar to the ones found in the Minas do Meio Mines belonging to the Itabira Complex. In the end, it was decided that this last facility would be selected as the place where the research would be developed.

Itabira Mine Complex is located at QF Northeast and consists of the Cauê Mine (non-active), the Conceição Mine,

exploitation occurs on a hillside, and the sub-grade and construction materials are less competent. Such differences have direct consequences in the pavement design and in the construction of the access roads. Also, ity performed haul roads management on its own, handling distinct practices, even within a limited area of coverage such as the QF.

In this paper, the current practice of the mine haul roads is re-evaluated by adopting a more quantitative approach, complementing the overall view covered in the 2009 research. It is expected that this diagnosis will be able to support relevant changes in the way these structures are designed, built and managed.
In addition, workshop events regarding design, construction and maintenance of mine haul roads were held, and finally all information about the practice in mine haul roads was formalized.

Gathering of accumulated experience allowed the compilation of all information related to the current practice regarding design, construction and maintenance of haul roads, from particular case studies to those more general situations. A qualitative and semi-qualitative approach was emphasized in it. This was the third part of work.

and the Minas do Meio Mines (Dois Córregos, Periquito, Onça, Chacrinha and Corpo D). Oliveira Filho et al. (2010) concluded that in this Complex, there is a clear distinction of the efforts spent in the construction and maintenance steps of the haul roads, which are greater than those related to the design, in any kind of access.

they lead to distinct geometry and drainage definitions, besides requiring differentiated maintenance care. In Figure 1a and Figure 1b, Minas do Meio Mines and Conceição Mine overviews are respectively shown.

Figure 1

Mine Overviews in the Itabira Complex: (a) Minas do Meio; (b) Conceição. 


\section{Geometric design}

In the alignment of a road, the design speed and design vehicle are the conditioning factors of the geometric design (BRASIL, 1999). However, in mining, design speed is not a conditioning issue of the geometric design. Haul roads are designed by trying to place it in the available space and for a specific load vehicle.

In general mine planning, there is no definition of a design speed, but the place where the alignment should pass, and also a premise of a maximum grade. For long term planning, the goal is to define the final bench conformation. For medium term planning, some road characteristics are observed. However, it is only in the short term planning that

where: $\mathrm{w}$ is the road width, $\mathrm{x}$ is the

Stopping and sight distances are not directly verified in the current mine roads.

As far as the maximum sustained grade, for secondary accesses the practical value is $1 \%$. This is controlled by the min-

Figure 2 Irregular grade in a main road.

Regarding vertical and horizontal curves, their configuration is defined during road implementation. In the horizontal curves, maximum radius is a priority, with $30 \mathrm{~m}$ minimum, although it is possible to find curve sections with a lower radius because of physical limitations. There is also a concern to avoid coincidence of horizontal and vertical curves. In relation to the extra width in curves, this feature, in general, is not implemented.

Superelevation to help vehicle turn in curved sections and cross-slopes to avoid diffuse flow on the surface in straight roads are in fact taken into account. Thus, in the annual planning, roads have their alignment, and in the monthly planning, operational issues are dealt with.

Also with respect to alignment, if the accesses are intended to mining of benches (identified as a "secondary access"), their geometry is defined by the exploitation plan. Regarding access destined to product transportation (also called "main access" or "main roads"), priority is given to maximum straightness. As far as the design vehicle, all haul roads should be designed, regardless of their class, to attend the largest vehicle using the road (Kaufman \& Ault, 1977).

The geometric design of mine haul roads considers in general the follow-

$$
w=(1,5 \mathrm{x}+0,5) \mathrm{L}
$$

number of lanes, $\mathrm{L}$ is the width of the

ing equipment (excavator), which should use the road at end of mining or during a temporary interruption of the mining front. For main accesses, the sustained grade is determined by the trucks. Major ing elements: road width, stopping and sight distances, maximum sustained grade, vertical curves configuration, super-elevation, cross-slope for drainage, horizontal curves alignment, extra width on curves, harmonization between horizontal and vertical alignments, and spacing between safety berms.

Related to road width, there is a minimum criterion, enforced by Brazilian mining safety rules, of two times the width of the largest vehicle using the road with one lane, and three times for roads with two lanes. In general this rule is observed, but if there is road allowance, those values could be increased by applying equation 1 , which is well accepted in mining.

Equation 1

largest vehicle using the road.

efficiency is sought through engine power and gross weight, which lead to a maximum grade from 8 to $12 \%$. A critical point is the grade regularity, a target issue, but not always reached, as shown in Figure 2.

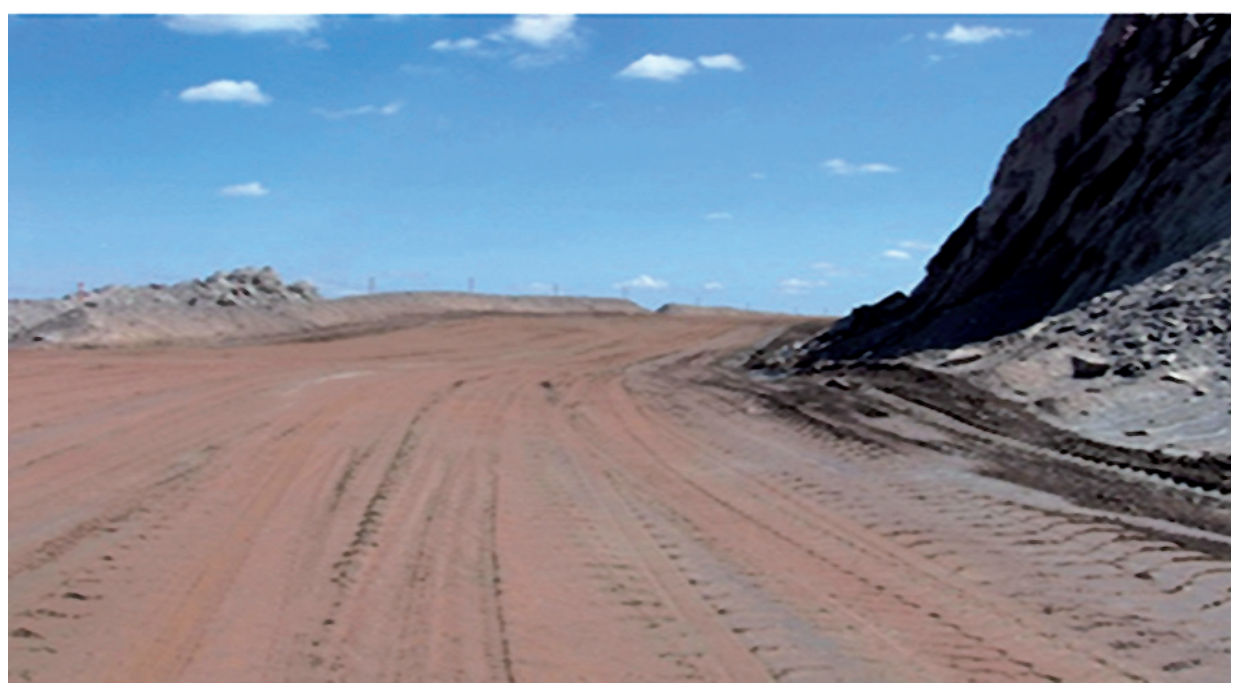

sections is not used in secondary accesses, since there is a possibility of traveling of mining equipment. In the case of main roads, this feature is usually, at least in the majority of them, and their help is recognized. Exception may occur in curved sections with large radii, or if the curve occurs in a graded stretch of the road. For grades over $5 \%$ plus a $3 \%$ cross-over (typical value), slippery conditions for trucks could be present.

The geometry of the safety berms is a trapezium with a large base. Typical height of $2.5 \mathrm{~m}$ is beyond the minimum required according to a Brazilian mining regulation (BRASIL, 2001), of rolling radius of the vehicle's tire, in the case the CAT 793. The safety berms are discontinuous in secondary accesses to allow for drainage, and continuous in the main road where water flow is directed to the foot slope (internal road border).

Summing up, the road geometric definition is based on the Mining Plan. Only alignment and maximum grade are designed before road construction. All other features are known during the road implementation and for some of them 
there are typical values, but there is not a formal design.

\section{Pavement design}

Road pavement is a structure intended to: (a) resist and distribute to sub-grade vertical loads caused by traffic; (b) improve rolling conditions regarding smooth and safe driving; and (c) resist to horizontal forces (shear forces) providing high durability to the rolling surface (ABNT, 1982).

Typically, a pavement is a layered system, each layer with a distinct function. The upper layer is called wearing course layer and should resist to a high level of vertical normal (caused by vehiclés weight) and shear stresses (related to vehicle's traffic). This layer has a functional and structural character. Below the wear- ing course, there is the base, which is the layer also intended to resist high vertical stresses. The horizontal forces reaching this layer are much lower or negligible. The sub-base, below the base, should resist vertical normal stresses, but at a lower level than those which reach the base. A fourth layer called sub-grade reinforcement could be necessary, and is used in situations where the foundation's pavement (sub-grade) has low bearing capacity. These last three layers have a structural function. In this layering concept, as it approaches to load application, from the sub-grade upwards, better should be the layer construction material. However, it is

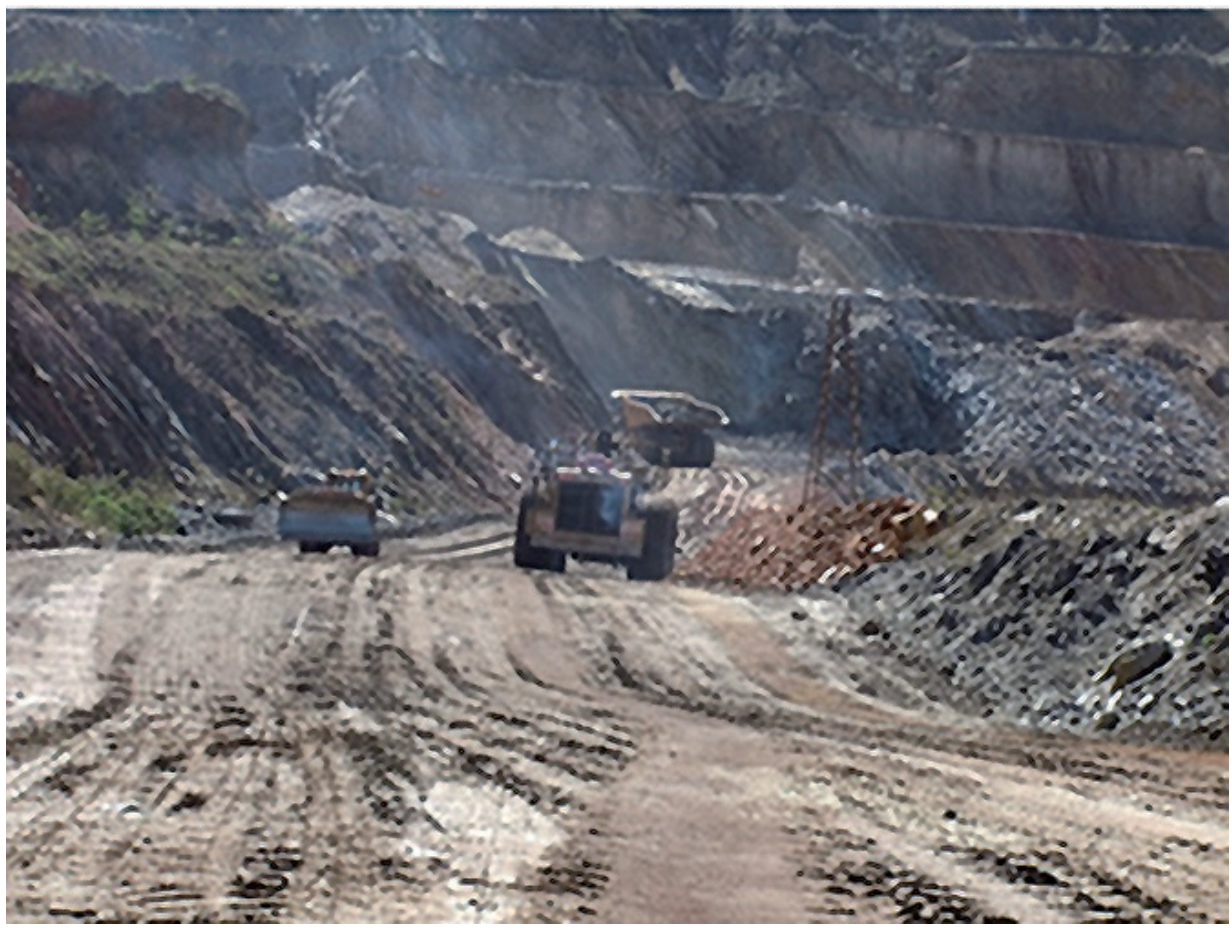

Main roads pavement arrangements broadly consist of a wearing course and base layers, forming a $2 \mathrm{~m}$ thick structure, although in some cases a sub-base and even a sub-grade rein- forcement are also included. The main conditioning factor in pavement definition is the size of the rock fragments that form the construction material. These fragments can be as large as one-meter not always necessary to build a pavement with all these different layers. This will depend of a proper pavement design and material availability.

In the current mining practice, there is no such a pavement design but some empirical definitions. In the secondary accesses, because of the superior quality of the material conditions and low level of efforts, only a regularization of the mining surface is required. However, if the mining front is far, the primary wearing course layer (also known as "lining" or "forro", in Portuguese) is usually built. In Figure 3 there is an example of this kind of pavement solution.
Figure 3

Surface conditions in a secondary road.

diameter. For main roads in the waste dumps, the pavement structure consists only of a one meter wearing course layer. In Figure 4 it is shown a typical main road.

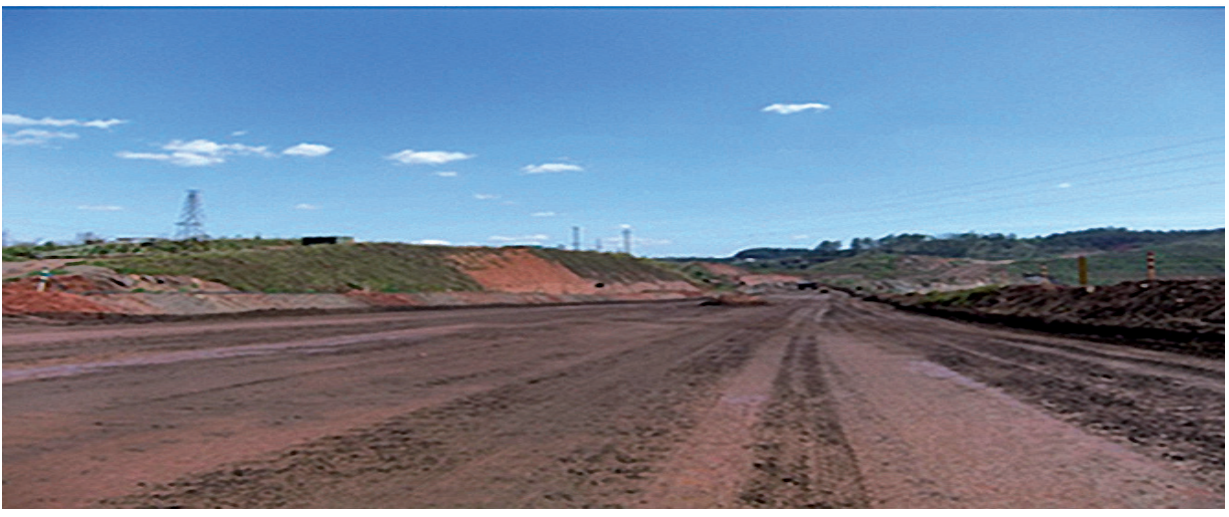

Figure 4

Surface conditions of a main road. 
The evaluation of sub-grade bearing capacity is necessary for design. However, in mining this property is not well-known. Instead, an idea of subgrade quality is obtained by qualitative (and empiric) approach by ripping foundation material. Availability of construction material properties is also necessary for pavement design. However, broadly what exists is only the accumulated experience based on previous projects.

Regarding the pavement functional aspect, two points are worth mentioning: adhesion between road surface and tires, and rolling resistance. The adhesion de-

\section{Drainage design}

The drainage system of a mine haul road and the drainage system of the open pit are often mixed up. It is necessary to make a distinction between them in order to have efficiency and avoid re-working.

Another relevant aspect is the fact that commercial mine development softwares in general do not deal with drainage, or if they do, it will be in a very simplified way. Thus, there is always

Figure 5

Unifilar diagram of the main haul road drainage system in a mine open pit.

In Figure 5, the three upper rectangles are the water sources; the gray rectangles represent the drainage gadgets in the road; and the bottom rectangle refers to a drainage device which is recipient of all mine drainage. As it can be noticed, the three-flow routing pends on material type and quality, and rolling resistance is impacted by road conditions. As happens to construction materials for the structural function, selection of wearing course material is also based on previous performance. This approach brings some difficulty when it is necessary to use new materials, with a possible influence on adhesion.

Rolling resistance is a parameter that has its importance recognized by the industry. It is often taken as a premise for main roads with a value of around $2 \%$, although higher numbers can be commonly found in the field. For secondary

a planning problem: drainage is usually considered tardily in the short term plan, which often is not the best time. There are also no reports on previous studies and there is lack of criteria in the definition of the design flood rate. Usually, a generic precipitation is adopted, configuring empirical attempts to define the critical rain.

In the secondary accesses in open accesses, rolling resistance well beyond that limit is tolerable.

Summing up, there is in general no pavement design for mine haul roads. Instead empirical definitions based on previous experience are adopted. Sub-grade bearing capacity is assessed empirically and there is no test data about the construction material. In the functional aspect, the premise of $2 \%$ rolling resistance is emphasized, although not always reached in practice. There is also difficulty to guarantee adhesion with new material, also because of lack of material properties.

pit mining, only $1 \%$ grade is possible, and this is the slope taken into account for drainage. Such declivity could direct a diffusion flow to the mining front or towards the inverse. In both cases, spaced lateral openings are used in the safety berm (called in Brazilian jargon "mustaches") for water removal. For main roads, several possibilities of superficial flow routing are shown in Figure 5.

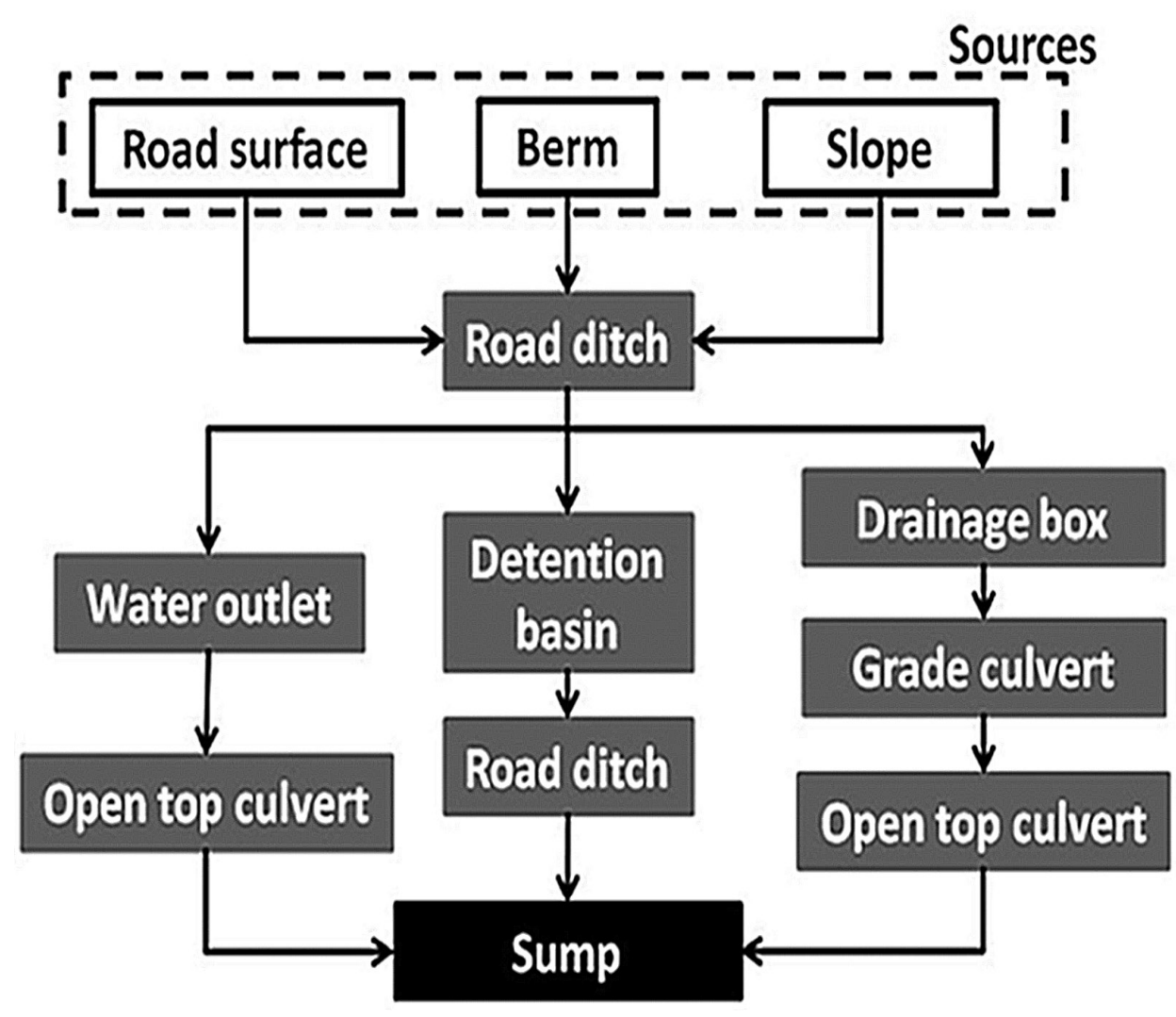

drains to the decant basin, also called mine "sump".

The best route is chosen depending on the road's surrounding conditions.

As indicated, the road drainage system is recipient of the major part of precipitated water in the mine. Some- times main roads act as flow channels for the mine drainage plan. In Figure 6, a case is illustrated where a main road receives flow from several benches. A risk to be avoided is to have a diffused flow on the main road due to lack of cross-slope or excessive flow. 


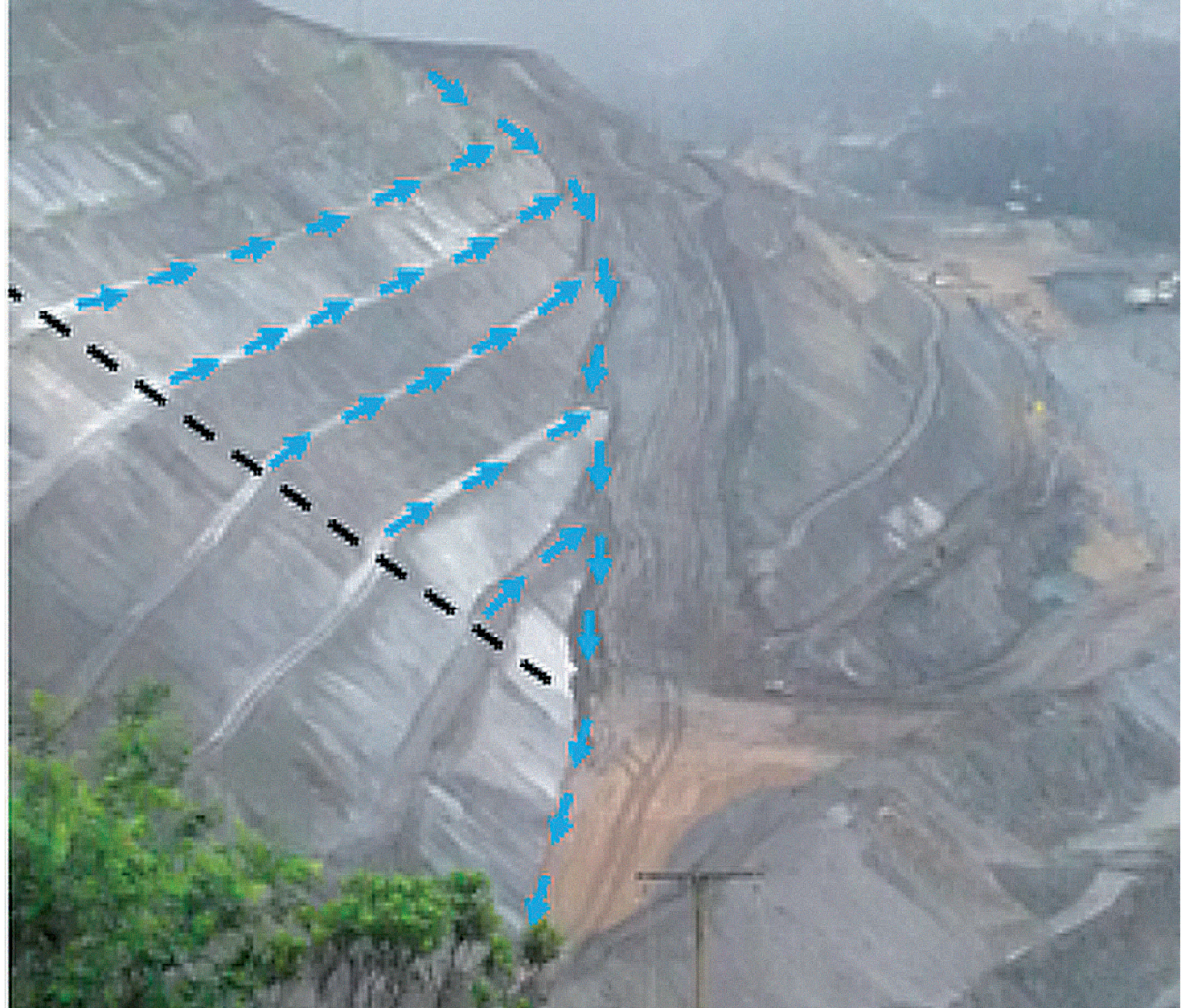

Another situation also found, which violates the drainage plan shown in Figure 5 , is observed when water flowing in one of the road sides (ditches) is directed to the other side, crossing the road superficially, not through a buried pipe (grade culvert).
Deep drainage systems are not found in open pit mines, mainly because of mine dewatering often used for exploitation feasibility.

In mine waste dumps, the drainage role is much more challenging due to
Figure 6

Inactive bench draining plan directed to a ditch in the main road.

higher traffic volume, in addition to worse sub-grade conditions. In these structures, the drainage system is not affected by road functionality, but by its location. In Figure 7 is shown several possibilities for routing the superficial flow in a mine waste dump.

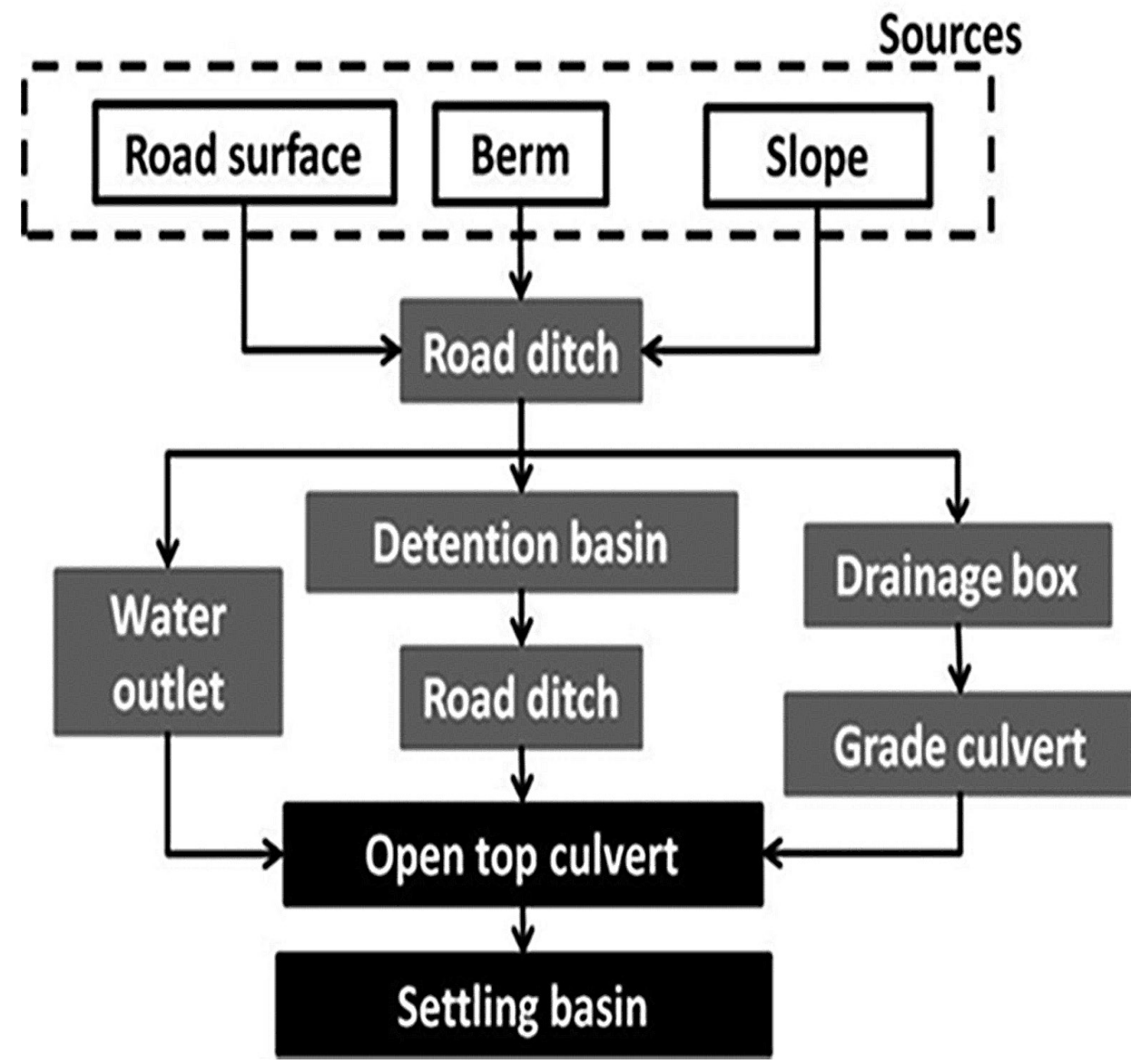

Figure 7

Unifilar diagram of the main haul road drainage system in awaste dump. 
In Figure 7, the superior rectangles refer to water sources; the gray rectangles represent road drainage gadgets; and the black rectangles are drainage devices, which are recipient of all waste dump drainage. Superficial flow routing in the waste dumps is very similar to the drainage system in the mine open pits. The only difference is in the water confluence, which flows downhill through a water step ladder (open top culvert) and then flows to the slimes decant basin. These last two structures belong to the mine waste dump drainage system, not to the roads.

\section{Construction}

When the design phase is concluded, construction of the haul road is next. Everything that was planned as desirable should be implemented. However, very frequently, directives pointed by the design have to be adapted, being possible even their total modification.

As mentioned, for main haul roads in pit, the implementation follows the directive of straight segments as much as possible. In secondary haul roads there is no such possibility, since the alignment has to follow the bench design development. However, if the proposed alignment is not applicable, a change must be discussed among builders (infrastructure personal) and designers (planning personal).

It is well recognized that is easier to implement haul roads in the waste dumps than in the pit, since the former structures obey a more regular pattern.

Construction initiates by earthmoving, which aims for sub-grade regularization through cut and fill operations. This makes the foundation terrain to be as close as possible to the finished grade, discounting pavement thickness. Besides grading, crosssloping for drainage is something that could also be configured during the earthmoving operation. This finishing

\section{Maintenance}

Maintenance efforts aim to keep or restore ideal operational conditions of the mine haul roads in order to permit safe traffic, an efficient operation, at compatible cost (BRASIL, 2006).

In the Itabira Complex the maintenance operations of the wearing course layer could be routine or exceptional. Among the routine maintenance that is brought to notice are watering, scrapping or grading, and material replacement; all
A relevant aspect in the mine waste dumps is the fact that what is known is the deposit final plan. An intermediate situation (during construction) is not designed. Tasks are performed as necessary, and this does not always happen in a successful way.

In the Itabira Complex, accesses which move mine ore or waste outside of the mine premises are rare. In these cases, they are more permanent and because of that, they need good traffic conditions. So, the drainage system quality should be on the same level as the main roads.

surface becomes the road sub-grade.

An issue related to earthmoving raised during the discussion on road construction in mining was if compaction belongs to this group. BRASIL (2009a) and $(2009 \mathrm{~b})$ consider that compaction is part of earthmoving, but in mining projects for haul roads, this operation does not exist; at least during construction. Broadly, fill materials or pavement layers are dumped and spread, and compaction is sought by traffic, recognized as random and superficial, and only performed in the operational phase. With that in mind, there is no way to guarantee that pavement has compactible strength with the load transferred by traffic.

As mentioned, construction materials are known uniquely by their applicability as pavement layers. In this instance, the best materials for usage as wearing course or base layers are wellknown; however their bearing capacity is not known. Another point of attention is their coarse texture. Due to the way they are produced through blasting and excavation, the bulk material often presents fragments as large as one-meter in diameter, which conditions the pavement thickness. An additional problem related to this coarse texture, is the stoniness character normally found on the road

of them performed aiming to attend the $2 \%$ rolling resistance requirement.

Watering of the wearing course layer aims to minimize dust problem. Two strategies are used: fixed watering, which has its application broadly justified in main roads and places close to communities; mobile watering, which could occur in any kind of haul road, in a permanent fashion, and is performed by water trucks. This operation tries to attend the demand and
In general terms, the drainage system works satisfactorily when implemented as described in Figures 5 and 7. However, in reality, there are situations where that design is not performed. Furthermore, there is no formalization of the design prior to the road implementation. The critical points in the drainage system are known, but the way to direct flow to these points and what to do with that floodwater are decisions taken in the field, during road construction. Highlighted also should be the empiricism in the definition of design precipitation.

surface, which considerably increases the rolling resistance and chances for tire damage. To mitigate the first problem, wearing course layer material needs the manual pick up of these rock pieces, specially the large ones. Another solution used in the past was to crush and classify this construction material before utilization. In these cases pavement thickness could be built as thin as $40 \mathrm{~cm}$.

In addition to the functional aspect, because mine haul roads are unpaved, there are records of utilization of dust suppression methods during the construction of wearing course layers. Because they could increase cohesion of the fine particles, dust suppression products have the potential to reduce dust generation and decrease slippery conditions. However due to the complexity of their application (labor and equipment) and questionable durability, the use of such substance was discontinued in the haul roads of the Itabira Complex.

Summing up, it could be said that construction techniques in the mine haul roads in the Itabira Complex still need improvement. Assessment of the sub-grade bearing capacity is empirical, construction material properties are not well-known, and compaction is not seen as a necessary operation in this phase.

is often evaluated. Nevertheless, problems related to slippery surfaces due to excessive wetting, or lack of visibility due to excessive dust, are common.

Scrapping and grading aim to remove superficial material found excessive loose or wet. This is accomplished with a motor grader (patrol), which performs small fill and cut compensations, directing the exceeded material to the road borders. Such an operation is illustrated in Figure 8. 


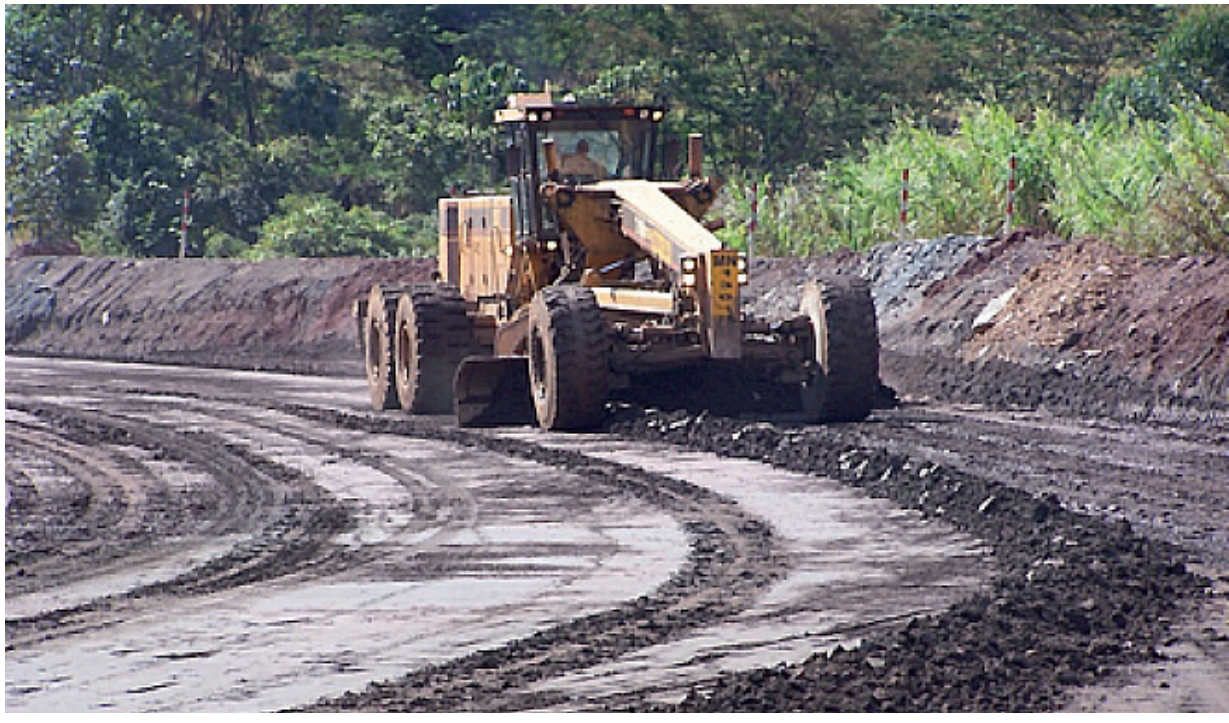

Unfortunately the surface regularization benefit, without compaction, is short lived or is limited, for part of the material continues to be loose under the surface. This operation is completed very often with removal of the material accumulated on the road shoulders and ditches using a dozer tractor or a loader, and material being discarded by means of load trucks.

Removal of the material which falls from crowned trucks could also be performed by scrapping. If it is a large amount, this material is accumulated and removed afterwards. If it is small, the road surface is scrapped, directing this material to the roadsides.

Material replacement is the third wearing course maintenance operation which was identified for the mine haul roads. It is necessary when expressive pavement thickness has been removed by the maintenance operations (scrapping) in order to avoid structural damage. It could be routine or structural, local or

\section{Conclusion}

Haul road conditions in the Itabira Mine Complex were found representative of iron ore mines in the Quadrilátero Ferrífero in Minas Gerais State since the site presents average climatic conditions, different types of open pit mining, besides a good diversity of construction materials and sub-grades.

In general terms, haul roads in the Itabira Complex are in good standing. There is compatibility between road conditions and their functionality in most cases, and accesses are defined within the mine general plan. However, design has little significance. Some definitions extensive. Local replacement (routine) is performed in general by making use of the material standing on the borders, even knowing that such material could be contaminated or more than ideally wet. In this case, motor graders do almost the entire work. This operation could also be performed using external material, like those whose source is a mining front or a waste dump. Previous to replacement, there is a local preparation by removing all remaining loose or wet material; this work is usually done by a loader or an excavator. Next, replacement material is brought to the area by trucks. After dumping, the material is spread in the area by a tractor (dozer). Extensive replacement follows what was defined for local replacement, but this operation happens only with borrowed material.

Besides routine maintenance operations, there could be exceptional operations, which could be very significant, as to rebuild the whole stretch or even the access in its integrity. Routine operations are established prior to construction, but these are not enough to formally configure a design. Regarding mine haul road geometry, there are directives for alignment and maximum sustained grade, but all other characteristics are discussed during road implementation. In respect to road pavement, the available approach relies on empirical procedures to define its overall characteristics and to assess sub-grade bearing capacity. Besides, construction material properties are unknown, and no method is used for pavement design. As far as drainage, what calls attention is the fact that very
Figure 8

Scrapping or grading

operation on a main road.

are justified and performed in any kind of haul roads; however exceptional maintenance applies only to main roads.

Maintenance of drainage systems has its feasibility guaranteed by routine road inspection. During this kind of inspection, defects or deficiencies are identified and could be fixed. Common maintenance operations include: clearing dirt from the detention basin, clearing dirt from the collection box of grade culverts, clearing of water outlets and ditches, correction of road cross-slopes, restoration of grade culverts and replacements of damage pipes.

Safety berms are also serviced by maintenance works, guaranteeing physical integrity of their slopes and base, with a prompt correction of their problems.

In short, the general assessment of mine haul road maintenance is that the operations attend the technical standards for unpaved roads. However, attention should be given to frequency and the way these operations take place. often the road drainage system and mine drainage system are mixed up with roads and are handled as flow channels. Some flow routing could be identified, but their design is poorly based, such as a sort of generic rainfall event.

In road construction, the major impact over future road operational conditions is due to lack of compaction according to the available technology. Finally, maintenance work practices are satisfactory and could attend to the production needs, although it could be minimized in case more attention is given to design and construction. Also 
in maintenance services, the absence of

\section{Acknowledgments}

Authors thank The Federal University of Ouro Preto and FAPEMIG under

\section{References}

TEC 00181/10 grant for their support to this research.

ASSOCIAÇÃO BRASILEIRA DE NORMAS TÉCNICAS. ABNT. NBR 7207: Terminology and Classification of Pavement. Rio de Janeiro, 1982. 3p. (In Portuguese)

BRASIL. National Highway Department. Tecnological Development Directory. Technological Training Division. Highway Geometric Design Manual. Rio de Janeiro, 1999. 195p. (In Portuguese)

BRASIL. National Mineral Production Department. Act 237. Brazilian Mining Regulations. Brasilia, 2001. 94p. (In Portuguese)

BRASIL. National Transport Infrastructure Department. General Studies and Research Coordination. Highway Research Institute. Pavement manual. 3rd. ed. Rio de Janeiro, 2006. 333p. (In Portuguese)

BRASIL. National Transport Infrastructure Department. Highway Research Institute. Earthmoving - Cuts - Service Especifications. Rio de Janeiro, 2009a. 12p. (In Portuguese)

BRASIL. National Transport Infrastructure Department. Highway Research Institute. Earthmoving - Fills - Service Especifications Rio de Janeiro, 2009b. 13p. (In Portuguese)

KAUFMAN, W. W., AULT, J. C. Design of Surface Mine Haulage Roads - a Manual. Pittsburgh, 1977. 49p.

OLIVEIRA FILHO, W. L. Unpaved Mine Haul Roads. FAPEMIG Research Project. TEC 00181/10. Ouro Preto, 2010. 13p. (In Portuguese)

OLIVEIRA FILHO, W. L., FERNANDES, G., VAN HAM, G.H.J., RODRIGUE S, C.A.F., SOUZA, L.M.L.S. Mine Haul Road Inventory Report. Ouro Preto, 2010. 187p. (In Portuguese)

Received: 30 August 2014 - Accepted: 3 October 2014. 